\title{
Preparation of a New Self-assembled Polyamide Film Containing Disulfide Bonds on a Gold Surface
}

\author{
Hiromori TSUTSUMI* and Takashi KURASHIGE
}

Received April 21, 1994 ; Accepted May 20, 1994

\section{INTRODUCTION}

The self-assembly of organic molecules including sulfur atom, such as thiol, disulfide, on a gold surface is one of the attractive phenomena to prepare a monolayer film modified electrode ${ }^{1}$ ). This method is simple and alternative to Langmuir-Blodgett technique. Many investigations on basic characteri zation of the monolayer film modified electrodes and their applications have been reported ${ }^{2}$ ). However, few polymeric analogs to modify a gold or other metal surfaces have been prepared ${ }^{3-5}$ ). In this paper we report a preparation of a new polyamide that have disulfide bonds in its main chain, poly[imino(3,3'-dithiodipropionyl)-imino(2,2'dithiodiethyl)], polyamide (I), (Scheme I). Furthermore, specific interaction between iodine and the polymer is also suggested by electrochemical and infrared measurements for the modified electrodes.

Scheme I. Structure of polyamide(I).

$-\left[\mathrm{NHCO}-\left(\mathrm{CH}_{2}\right)_{2}-\mathrm{S}-\mathrm{S}-\left(\mathrm{CH}_{2}\right)_{2}-\mathrm{CONH}-\left(\mathrm{CH}_{2}\right)_{2}-\mathrm{S}-\mathrm{S}-\left(\mathrm{CH}_{2}\right)_{2}-\mathrm{Jn}-\right.$

\section{EXPERIMENTAL}

Polyamide(I) was prepared by condensation of 3,3'-dithiodipropionic acid and cystamine with interfacial polymerization technique. The diacid was converted to the acid dichloride by heating for 90 min under reflux with excess thionyl chloride. The cystamine aqueous solution ( $24 \mathrm{mmol} / 100 \mathrm{ml}$ ) containing $\mathrm{NaOH}(96 \mathrm{mmol})$ was added to the acid dichloride/ $\mathrm{CCl} 4$ solution (24 $\mathrm{mmol} / 100 \mathrm{ml}$ ). The polymer was purified by reprecipitation of polyamide(I)/formic acid solution from methanol (Total yield 73\%). Structure of polyamide(I) was confirmed with IR, ${ }^{1} \mathrm{H}$-, and ${ }^{13} \mathrm{C}$-NMR measureDepartment of Applied Chemistry \& Chemical Engineering, Faculty of Engineering (Yamaguchi University, Ube, 755 Japan)

Key Word: Self-assembly, Polyamide, Modified Electrode, Disulfide ments. IR $\left(\mathrm{cm}^{-1}\right) 1644$ (amide I), 1545.5 (amide II), ${ }^{1} \mathrm{H}$ $\operatorname{NMR}(\delta, \mathrm{ppm}) 3.91\left(4 \mathrm{H},-\mathrm{CH}_{2}-\mathrm{CONH}-\right), 3.11(8 \mathrm{H}$, $\left.-\underline{\mathrm{H}}_{2}-\mathrm{S}\right), 2.99\left(4 \mathrm{H},-\mathrm{CH}_{2} \mathrm{NHCO}-\right),{ }^{13} \mathrm{C} \operatorname{NMR}(\delta$, ppm) $179.2,41.3,41.1,36.4,32.9$.

Hydroxymethylferrocene and $\mathrm{N}, \mathrm{N}$-dimethylaminomethylferrocene methiodide were prepared according to the literature ${ }^{6}$ ).

Preparation of the polymer modified electrode was performed as in the following procedure: a gold sputtered glass plate $(0.5 \mathrm{~cm} \times 1.0 \mathrm{~cm})$ was dipped into a $10 \mathrm{mmol} \mathrm{dm}^{-3}$ polyamide(I)/formic acid solution for $24 \mathrm{~h}$ at room temperature $\left(20-25^{\circ} \mathrm{C}\right)$ and washed with formic acid and water (purified by a Milli-Q purifying system) repeatedly. The modified electrode was used within $24 \mathrm{~h}$ after preparation. Electrochemical measurements were performed at $25^{\circ} \mathrm{C}$ in a conventional threeelectrode cell consisting of a working electrode (a gold sputtered glass plate or polymer modified electrode, surface area $0.5 \mathrm{~cm}^{2}$ ), a $\mathrm{Pt}$ electrode as the counter electrode (surface area $12.5 \mathrm{~cm}^{2}$ ), and a saturated calomel electrode (SCE) as the reference electrode. All solutions for electrochemical measurements were purged with $\mathrm{Ar}$ gas for $30 \mathrm{~min}$ prior to use.

\section{RESULTS AND DISCUSSION}

Modification of polyamide(I) on a gold substrate was confirmed by FTIR reflection adsorption spectroscopy (RAS). The peaks at 1644 and $1545.5 \mathrm{~cm}^{-1}$ attributed to amide I and amide II band 7) in the polyamide(I) were clearly observed in the RAS spectrum of the polyamide(I) modified electrode.

The cyclic voltammogram for polyamide (I) modified electrode in $0.2 \mathrm{~mol} \mathrm{dm}^{-3} \mathrm{Na}_{2} \mathrm{SO}_{4}$ aqueous - solution showed the capacitive current and no obvious peaks in the range between -0.2 and $0.6 \mathrm{~V}$. Furthermore the peak height and the shape of the cyclic voltammogram for polyamide(I) modified electrode in 
aqueous solution containing $0.2 \mathrm{~mol} \mathrm{dm}-3 \mathrm{Na}_{2} \mathrm{SO}_{4}$ and $1 \mathrm{mmol} \mathrm{dm}^{-3}$ hydroxymethylferrocene was similar to those for a bare electrode (observed redox response at $0.219 \mathrm{~V}$ and $0.160 \mathrm{~V}$ ). Thus the polyamide(I) on the electrode did not prevent electron transfer between the electrode and the redox species in the bulk solution. It suggests that the coated film on the electrode is very thin. Figure 1 shows the cyclic voltammograms for a polyamide(I) modified electrode and a bare gold electrode in aqueous solution containing $0.2 \mathrm{~mol} \mathrm{dm}^{-3}$ $\mathrm{Na}_{2} \mathrm{SO}_{4}$ and $1 \mathrm{mmol} \mathrm{dm}^{-3} \mathrm{~N}, \mathrm{~N}$-dimethylaminomethylferrocene methiodide. In anodic scan the shape and the height of the peak in the voltammogram for the modified electrode are same as those for the bare electrode. In cathodic scan the bare electrode shows two peaks $\left(\mathrm{P}_{\mathrm{c}} 1\right.$ at $0.430 \mathrm{~V}$ and $\mathrm{P}_{\mathrm{c} 2}$ at $\left.0.360 \mathrm{~V}\right)$. The modified electrode shows two peaks $\left(P_{\mathrm{c} 1}\right.$ at $0.430 \mathrm{~V}$ and $P_{\mathrm{c} 2}$ at $0.385 \mathrm{~V}$ and one shoulder peak ( $P_{\mathrm{c} 3}$ about $\left.0.360 \mathrm{~V}\right)$. According to the literature 8,9$), \mathrm{P}_{\mathrm{cl}}$ corresponds to the reduction current of iodine produced by oxidation of iodide ion and $P_{\mathrm{C} 2}$ and $\mathrm{P}_{\mathrm{C} 3}$ are attributed to the reduction of ferrocenium to ferrocene. Decrease of $\mathrm{P}_{\mathrm{cl}}$ and increase of $P_{C 2}$ ' are observed for the polyamide(I) modified electrode. The variation in the quantity of electricity for $P_{c 1}$ $\left(\Delta \mathrm{QPc} 1=176 \mu \mathrm{Ccm}^{-2}\right)$ is nearly equal to that for $\mathrm{P}_{\mathrm{C} 2}$ $\left(\Delta \mathrm{Qpc}^{\prime}=136 \mu \mathrm{Ccm}^{-2}\right)$. It suggests that the reduction potential of iodine shifts more negative and overlaps the reduction peak of ferrocenium ion. The potential shift indicates the stabilization of iodine on the polyamide(I) modified electrode. Interaction between iodine and polyamide(I) is confirmed by the infrared spectrum of polyamide(I) treated with iodine vapor. The peak of amide I and amide II shifted to lower wavenumber, (amide I, from $1644 \mathrm{~cm}^{-1}$ to $1636 \mathrm{~cm}^{-1}$, amide II, from $1545.5 \mathrm{~cm}^{-1}$ to $1538.8 \mathrm{~cm}^{-1}$ ) after the iodine-dope treatment. This suggests the complex formation between polyamide(I) and iodine, $-\mathrm{C}=\mathrm{O} \cdots \mathrm{I}_{2}$ and/or $\mathrm{HN}$... I2. Formation of similar polyamide-iodine complex has been observed 10 ). Therefore, $P_{c 2}$ is attributed to the reduction current of the iodine adsorbed by the polyamide(I) molecules on the electrode. Detail investigation of the modified electrode is now in progress.

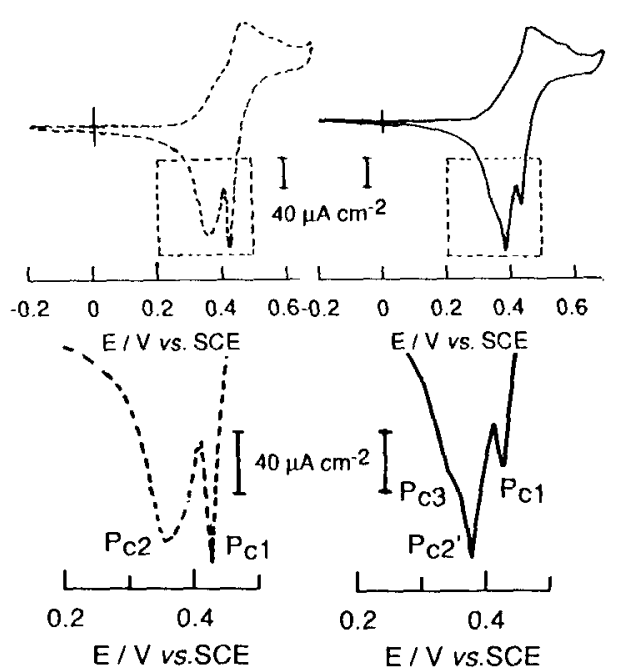

Fig. 1 Cyclic voltammograms for a bare gold electrode (broken line) and polyamide(I) modified electrode (solid line) in aqueous solution containing $0.2 \mathrm{~mol} \mathrm{dm}^{-3}$ $\mathrm{Na}_{2} \mathrm{SO}_{4}$ and $1 \mathrm{mmol} \mathrm{dm}^{-3} \mathrm{~N}, \mathrm{~N}$-dimethylaminomethylferrocene methiodide. Scan rate $5 \mathrm{mV} \mathrm{s}^{-1}$.

\section{REFERENCES}

1) C. D. Bain and G. M. Whitesides, Angew. Chem. Int. Ed. Engl., 28, 506 (1989).

2) A. Ulman, An Introduction to Ultrathin Organic Films, Academic, Boston, 1991.

3) T. J. Lenk, V. M. Hallmark, J. F. Rabolt, L. Haussling and H. Ringsdorf, Macromolecules, 26, 1230 (1993).

4) M. Niwa, T. Mori and N. Higashi, Macromolecules, 26, 1936 (1993).

5) F. Sun and D. W. Grainger, J. Polym. Sci.:Part A:Polym. Chem., 31, 1729 (1993).

6) J. K. Lindsay and C. R. Hause, J. Org. Chem., 22, 355 (1957).

7) L. J. Bellamy, The Infra-red spectra of complex Molecules, chapter 12, pp. 231-262, Chapman and Hall, London, 1975.

8) N. F. Blom, E. W. Neuse and H. G. Thomas, Transition Met. Chem., 12, 301 (1987).

9) A. J. Bard and L. R. Faulkner, Electrochemical Methods fundamentals and Applications, pp.699702, John Wiley \&Sons, New York, 1980.

10) T. Yamamoto and S. Kuroda, J. Electroanal. Chem., 158, 1 (1983). 